\title{
EFEKTIVITAS REZIM KEBIJAKAN INFLATION TARGETING FRAMEWORK (ITF) TERHADAP INFLASI DI INDONESIA
}

\author{
Doni Briliant \\ Sekolah Tinggi Ilmu Ekonomi YKPN, donibriliant2013@gmail.com
}

\begin{abstract}
ABSTRAK
Sebagai otoritas moneter, Bank Indonesia diberi amanat oleh pemerintah untuk menjaga stabilitas nilai rupiah melalui rezim Inflation Targeting Framework. Meskipun kebijakan Inflation Targeting Framework telah dijalankan sejak tahun 2005, nyatanya, target inflasi baru dicapai secara konsisten pada empat tahun terakhir, dari 2015 sampai dengan 2018. Penelitian ini bertujuan menguji efektivitas kerangka kebijakan moneter yang sedang dijalankan oleh Bank Indonesia. Variabel yang digunakan dalam penelitian ini adalah Nilai Tukar Rupiah/USD, Jumlah Uang Beredar dalam arti sempit (M1), Inflasi Periode Sebelumnya, Dummy Inflation Targeting Framework sebagai variabel independen, dan Inflasi sebagai variabel dependen. Data yang digunakan adalah data tahunan dari tahun 1991 sampai dengan2018. Sedangkan metode penelitian ini adalah regresi berganda menggunakan Huber-White dengan bantuan E-views 9.0. Hasil penelitian menujukkan bahwa Nilai Tukar Rupiah/USD, Jumlah Uang Beredar, Inflasi Periode Sebelumya berpengaruh positif dan signifikan terhadap Inflasi. Selain itu, hasil penelitian juga menunjukkan bahwa Dummy Inflation Targeting Framework berpengaruh signifikan terhadap Inflasi.
\end{abstract}

Kata Kunci: Nilai Tukar, Jumlah Uang Beredar, Inflasi Periode Sebelumnya, Inflation Tagreting Framework, Inflasi

\begin{abstract}
As a monetary authority, Bank Indonesia is given a mandate by the government to maintain the value of Rupiah through the regime of Inflation Targeting Framework. Although the Inflation Targeting Framework regime has been run since 2005, in fact, the inflation target is constantly achieved in the last four years, as of 2015 to 2018. This research is aimed to examine the effectivity of the framework of monetary policy being run by Bank Indonesia. Variables used in this research are the Rupiah/USD exchange rates, the money in circulation in narrow definition, the previous period of inflation rates and the dummy of Inflation Targeting Framework as independent variables, and the inflation as dependent variable. Data used are yearly data from 1991 to 2018. Meanwhile, the research method in this study is multiple regression using HuberWhite with E-views 9.0. The results show that Rupiah/USD exchange rates, money in circulation, and previous period of inflation rates affect positively on inflation rates. Beside of that, the result also shows that the dummy of Inflation Targeting Framework affects significantly on the inflation rates
\end{abstract}

Keywords: Exchange Rates, Money in Circulation, Previous Period of Inflation, Inflation Targeting Framework, Inflation Rates

Naskah diterima : 15-05-2020, Naskah dipublikasikan : 30-09-2020 


\section{PENDAHULUAN}

Depresiasi Rupiah terhadap dolar Amerika pada 1997 membuat Bank Indonesia sebagai otoritas moneter merubah rezim moneter Indonesia dari sistemmanaged free floating with band intervention menjadi sistemmanaged free floating. Implikasi dari kebijakan tersebut adalah membuat Rupiah menjadi rawan terhadap goncangan baik dari dalam maupun luar karena bank sentral akan melakukan kontrol terhadap fluktuasi nilai tukar Rupiah seminim mungkin. Apabila terjadi goncangan terhadap Rupiah, hal tersebut akan diperparah dengan status Indonesia sebagai small open economy.

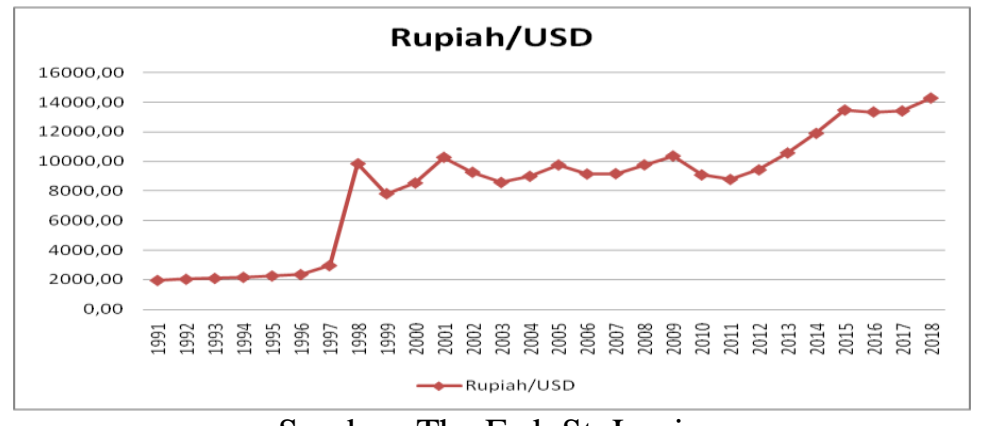

Sumber: The Fed. St. Louis

Gambar 1. Nilai Tukar Rupiah/Dolar Amerika 1991-2018

Berdasarkan Gambar 1 terlihat bahwa perubahan kebijakan moneter oleh Bank Indonesia pada Juli 1997 membuat nilai nominal. Pada periode akhir 1996, posisi nilai nominal Rupiah sebesar Rp 2.383/USD. Sepanjang 1997, kurs Rupiah/USDberangsur melemah. Pada awal 1998, rupiah terdepresiasi hebat dari Rp 4650/USD pada Desember 1997 menjadi Rp 10.375/USD. Langkah stabilisasi dengan kebijakan kontraktif yang dilakukan oleh Bank Indonesia dan pemerintah berhasil membuat nilai tukar Rupiah recovery menjadi Rp 7500/USD (Musa, 2008). Namun, Rupiah kembali terdepresiasi ke titik terendahnya selama Krisis 1998, yaitu pada Rp 14.900/USD. Sebagai respon atas kritik independensi Bank Indonesia, pemerintah memberlakukan UU No. 23 tahun 1999 tentang Bank Indonesia, dimana inti dari undangundang tersebut adalah tugas tunggal bagi Bank Indonesia yaitu menjaga stabilitas nilai Rupiah. Sejak Juli 2005, Bank Indonesia menetapkan sasaran inflasi sebagai sasaran tunggal dengan kerangka kebijakan yang disebut dengan Inflation Targeting Framework (ITF). Dengan demikian, fokus kebijakan pada sasaran inflasi serta proses pencapaian kebijakan makroekonomi lainnya seperti pertumbuhan ekonomi dan membuka kesempatan kerja dapat dilakukan(Ismail, 2006).

Penggunaan ITF sebagai kerangka utama dalam kebijakan moneter dilakukan dengan menyatakan besaran sasaran inflasi untuk kemudian mengarahkan ekspektasi dan inflasi aktual ke dalam sasaran yang telah ditetapkan (Setiawan, 2011). Menurut Vega dan Winkelried (2005), kebijakan ITF menekankan pada ciri keseluruhan bahwa kebijakan tersebut dibangun atas dasar kredibilitas. Kredibilitas yang dimaksud adalah kemampuan bank sentral untuk menetapkan dan mengarahkan ekspektasi jangka panjang untuk menghindari jebakan ekspekasi yang mungkin menyumbang pada nilai inflasi itu sendiri.

Tabel 1. Target dan Aktual Inflasi

\begin{tabular}{|c|c|c|c|c|c|c|c|c|c|c|c|c|c|}
\hline Periode & $\mathbf{2 0 0 5}$ & $\mathbf{2 0 0 6}$ & $\mathbf{2 0 0 7}$ & $\mathbf{2 0 0 8}$ & $\mathbf{2 0 0 9}$ & $\mathbf{2 0 1 0}$ & $\mathbf{2 0 1 1}$ & $\mathbf{2 0 1 2}$ & $\mathbf{2 0 1 4}$ & $\mathbf{2 0 1 5}$ & $\mathbf{2 0 1 6}$ & $\mathbf{2 0 1 7}$ & $\mathbf{2 0 1 8}$ \\
\hline $\begin{array}{c}\text { Target } \\
\text { Inflasi } \\
(\boldsymbol{\%})\end{array}$ & $5-7$ & $7-9$ & $5-7$ & $4-6$ & $3,5-$ & $4-6$ & $4-6$ & $3,5-$ & $3,5-$ & $3,5-$ & $3-5$ & $3-5$ & $2,5-$ \\
\hline $\begin{array}{c}\text { Actual } \\
\text { Inflation } \\
(\%)\end{array}$ & 17,11 & 6,6 & 11,06 & 2,78 & 6,69 & 3,79 & 4,30 & 8,38 & 8,36 & 3,35 & 3,02 & 3,61 & 3,13 \\
\hline
\end{tabular}

Sumber: Bank Indonesia 
Berdasarkan tabel di atas, pencapaian atas kebijakan ITF belum dapat dikatakan memuaskan, ketika dimulai pada tahun 2005, hasil operasi dari ITF meleset jauh dari target. Hal ini dapat dimaklumi karena Indonesia sedang dalam proses trial-error dalam pengaplikasian kebijakan tersebut. Namun seiring dengan berjalannya waktu, kemampuan ITF dalam menggiring ekspektasi inflasi mulai terbukti, paling tidak hal tersebut dibuktikan dengan nilai inflasi yang berada dalam target inflasi oleh Bank Indonesia dalam empat terakhir, dari 2015 sampai dengan 2018.

Meskipun arah dari kebijakan ITF cukup meyakinkan bagi Indonesia, namun terdapat beberapa pendapat kontra atas penggunaan kebijakan tersebut. Agung et al., (2001) menjelaskan alasan mengapa sebaiknya Bank Indonesia tetap menggunakan base money sebagai target kebijakan moneter. Pertama, pada kondisi krisis, permintaan uang akan memberikan arah yang lebih jelas tentang pengambilan keputusan terkait operasi moneter daripada inflasi dan suku bunga. Selain itu, suku bunga juga akan mengalami volatilitas yang cukup tinggi apabila dikaitkan dengan resiko premi ketika kondisi krisis terjadi. Kedua, meskipun pada faktanya base money targeting sulit dilakukan dalam rangka membangun kredibilitas bank sentral ketika fungsi intermediary bank tidak berjalan semestinya, namun base money targeting dianggap masih lebih mudah dilakukan karena peran bank sentral itu sendiri sebagai otoritas moneter daripada menggunakan target inflasi, dimana inflasi selalu dipengaruhi oleh kondisi yang tidak pasti. Ketiga, pelaku ekonomi cenderung menganggap bahwa bank sentral akan selalu mengorbankan kepentingan jangka pendek seperti laju inflasi demi mencapai kondisi pasar uang dan sektor riil yang diharapkan, hal ini tentunya menyangkut kredibilitas bank sentral apabila dikaitkan dengan ekspektasi pelaku pasar.

Terdapat beberapa penelitian terdahulu yang membahas keterkaitan inflasi dengan target operasi moneter sebuah negara. (Dewayany, 2012)menjelaskan keterkaitan inflasi dan kebijakan moneter dalam kerangka Inflation Targeting Framework. Penelitian tersebut mengemukakan bahwa inflasi dipengaruhi oleh volatilitas kurs Rupiah/USD, Jumlah uang beredar, persistensi inflasi dan penggunaan target inflasi oleh Bank Indonesia.

Pengaruh negatif nilai tukar terhadap inflasi ditunjukkan oleh penelitian Ningsih dan Kristiyanti (2018), dimana hasil penelitan tersebut menyatakan bahwa depresiasi nilai rupiah atas Dolar Amerika akan meningkatkan indeks harga domestik khususnya yang bersumber dari material impor, dimana hal tersebut akan membuat daya beli masyarakat menurun. Dengan kata lain peningkatan harga barang domestik mayoritas akan meningkatkan inflasi.

Perubahan harga selalu diimbangi dengan peningkatan penawaran uang oleh bank sentral. Hal ini terjadi karena permintaan terus menerus sektor riil akan produksi barang dan jasa akan membuat penawaran uang meningkat, dan apabila permintaan efektif dari sektor riil tidak mampu diimbangi oleh produksi output maka akan meningkatkan harga komoditas (Aprileven, 2013).

Guna mengaplikasikan kebijakan moneter yang kredibel dalam kerangka target inflasi, bank sentral perlu memahami inti dari perjalanan inflasi itu sendiri dan fenomena yang menyebabkan terjadinya persistensi inflasi (Hakim et al, 2017). Perilaku pelaku ekonomi akan membentuk ekspektasi inflasi yang bersifat backward looking dimana hal ini dapat sepenuhnya berbeda dengan apa yang diharapkan oleh bank sentral dalam upaya stabilisasi inflasi karena keterbatasan informasi yang dimiliki oleh pelaku ekonomi, oleh karena itu, kelambatan inflasi menuju tingkat equilibriumnya akan mempengaruhi pandangan tentang ekspektasi inflasi oleh pelaku ekonomi (Erceg \& Levin, 2003). 
Kredibilitas Bank Indonesia dalam menjaga stabilitas nilai rupiah dalam kerangka inflation targeting tidak bisa dikatakan ringan, terlebih lagi perilaku inflasi itu sendiri tidak dapat diprediksi secara pasti dan dipengaruhi oleh banyak faktor internal maupun eksternal. Meskipun Indonesia sudah menerapkan strategi ITF dalam kurun waktu 14 tahun sejak tahun 2005, nyatanya target aktual inflasi baru konsisten tercapai dalam waktu empat tahun terakhir ini sejak 2015. Oleh karena itu, kemampuan bank sentral menjalankan kebijakan yang kredibel tercemin dari keeratan antara target inflasi dengan inflasi aktual perlu didiskusikan lebih jauh lagi.

Berdasarkan latar belakang di atas, tujuan dari penelitian ini adalah menjelaskan pengaruh volatilitas nilai tukar rupiah, jumlah uang beredar, dan inflasi periode sebelumnya terhadap inflasi di indonesia pada periode sebelum dan sesudah kebijakan Inflation Targeting Framework. Selain itu, penelitian ini akan menguji efektivitas Inflation Targeting Framework terhadap inflasi di Indonesia.

\section{KAJIAN LITERATUR Inflasi}

Latumaerissa (2011) mendefinisikan inflasi sebagai kecenderungan kenaikan hargaharga umum secara terus menerus. Dalam penegertian ini, yang dimaksud dengan kenaikan harga tidak berarti kenaikan yang disebabkan kenaikan musiman seperti musim lebaran atau hari natal, namun kenaikan harga barang umum secara konstan dan memerlukan tindakan pengendalian dari pemerintah dan pihak terkait.

\section{Nilai Tukar}

Menurut Salvatore (1997), nilai tukar merupakan harga relatif dari perbandingan dua mata uang negara yang berbeda. Penggunaan sistem mata uang sebuah negara tergantung kondisi ekonomi politik negara yang bersangkutan. Beberapa sistem nilai tukar antara lain: Pertama, sistem nilai tukar tetap yaitu sistem kurs yang sengaja dipatok oleh pemerintah dalam jangka waktu tertentu. Manajemen nilai tukar ini dilakukan dengan mengandalkan sistem intervensi devisa negara. Kedua, sistem nilai tukar mengambang yaitu sistem kurs yang sengaja dibiarkan mengambang oleh bank sentral atau pemerintah, sehingga nilainya tergantung pada mekanisme pasar. Ketiga, sistem mengambang terkendali yaitu sistem kurs yang manajemennya dilakukan melalui intervensi bank sentral di pasar uang dalam rangka stabilisasi nilai tukar. Keempat, pegged exchange rate system yaitu sistem nilai tukar yang dipatok secara tetap terhadap nilai mata uang asing.

\section{Jumlah Uang Beredar}

Jumlah uang beredar adalah semua jenis uang yang terdapat dalam sebuah perekonomian. Jumlah uang beredar terdiri dari dua komponen. Pertama, Jumlah uang beredar dalam arti sempit yaitu peredaran uang kartal ditambah dengan uang giral yang dimiliki entitas masyarakat, korporasi, dan badan pemerintah. Kedua, Jumlah uang beredar dalam arti luas meliputi uang kartal,uang giral dan deposito berjangka, tabungan dan valuta asing (Sukirno, 2004).

\section{Inflasi Periode Sebelumnya}

Inflasi periode sebelumnya akan membentuk sebuah pengharapan pelaku ekonomi tentang besaran inflasi riil yang diharapkan terjadi. Kondisi ini lazim disebut dengan ekspektasi inflasi. Kondisi ini terjadi apabila pelaku ekonomi melakukan keputusan ekonomi berkaitan dengan harga produksi dimana hal tersebut didasarkan pada kondisi inflasi masa lalu meskipun tidak ada tanda pasti akan terjadinya tekanan permintaan yang mempengaruhi kapasitas produksi pelaku ekonomi tersebut. Menurut dasar pembentukannya, ekspektasi inflasi dipengaruhi oleh tiga kondisi. Pertama, persistensi inflasi yang tinggi di periode sebelumnya. 
Kedua, terjadinya kenaikan harga dari sisi penawaran secara terus menerus. Dan yang terkahir, inflasi penawaran yang didorong oleh kebijakan moneter yang akomodatif (Dewayany, 2012).

\section{Inflation Targeting Framework (ITF)}

Bernanke dan Mishkin (1997) pada intinya mendefinisikan Inflation Targeting Framework sebagai sebuah kebijakan yang mengakui inflasi sebagai target operasi moneter dan sebagai sasaran kebijakan moneter. Strategi utama dari framework ini merupakan penetapan target inflasi sebagai sasaran inflasi pada periode tertentu. Menurut Debelle dan Fischer (1995), secara teoritis bank sentral sebaiknya diberikan sasaran inflasi oleh pemerintah sebagai pemangku kepentingan untuk mencapai tingkat inflasi yang ditargetkan, meskipun bank sentral sebagai lembaga yang independen dapat saja mengkoreksi target inflasi yang terlalu berat untuk dicapai. Di sisi lain, target inflasi jangka dapat saja diabaikan oleh pemerintah guna mencapai target pertumbuhan ekonomi. Oleh karena itu, komunikasi tentang besaran inflasi harus dilakukan oleh bank sentral bersama dengan pemerintah guna mencapai kebijakan ekonomi yang harmonis tanpa ada konflik kepentingan diantaranya.

Setiap negara yang menggunakan kerangka ITF memiliki tingkat penerapan yang bervariasi tergantung pada kondisi perekonomian negara yang bersangkutan. Carare dan Stone (2003) membagi tingkat pengaplikasian kerangka ITF menjadi tiga rezim, yaitu fully fledged inflation atau FFIT, Electic Inflation Targeting atau EIT, dan Inflation Targeting Lite Countries atau ITL.

Rezim kebijakan FFIT menjadi rezim yang paling banyak digunakan sejak dekade 1990-an. Pada umumnya, negara dengan rezim FFIT memiliki tingkat transparansi kebijakan moneter yang tinggi guna mendukung akuntabilitas bank sentral dalam penetapan target inflasi tanpa mengorbankan pertumbuhan ekonomi pada level tertentu.

Rezim kebijakan EIT hanya dapat dilakukan dengan kebijakan moneter yang memiliki kredibilitas sangat tinggi, sehingga mampu menjaga inflasi pada target tertentu tanpa harus memaksimalkan transparansi kebijakan guna mencapai target inflasi. Negara yang mengadopsi rezim EIT memungkinkan untuk melakukan upaya stabilisasi harga dan tingkat output tanpa harus mengorbankan salah satunya, tentunya dengan didukung kondisi stabilitas sistem keuangan yang prima.

Sementara itu, negara yang mengadopsi rezim ITL dianggap sebagai negara yang sedang bertransisi dari rezim moneter broad-moneyregime, dimana negara ini sedang mengupayakan reformasi struktural guna penerapan rezim ITF yang kredibel. Implikasi dari rezim ini adalah tingkat kerentanan terhadap guncangan ekonomi yang begitu tinggi karena kredibilitas bank sentral yang relatif rendah.

\section{Pengembangan Hipotesis}

\section{Pengaruh Nilai Tukar terhadap Inflasi}

Koku et al., (2016)menguji pengaruh volatilitas nilai tukar terhadap inflasi di negara-negara Balkan barat seperti Albania, Serbia, dan Macedonia. Pengujian tersebut membuktikan bahwa nilai tukar memiliki pengaruh negatif yang sangat signifikan terhadap stabilitas harga di negara-negara tersebut. Selain itu, pengujian ini juga menyimpulkan bahwa, bagi ketiga negara tersebut, tekanan nilai tukar masih menjadi faktor utama dari pemicu inflasi.

Edwards (2006) meneliti tentang hubungan antara pass-through exchange rates dan keefektivan nilai tukar nominal dalam rezim Inflation Targeting.Hasil penelitiannya menunjukkan bahwa negara yang menganut kebijakan ITF mengalami penurunan pada pass-through dari perubahan nilai tukar ke inflasi. Kemudian, ia menunjukan bahwa penggunaan kebijakan ITF tidak menghasilkan peningkatan pada volatilitas nilai tukar. Selain itu, ia juga menunjukkan bahwa terdapat beberapa bukti bahwa negara yang menganut sistem ITF dengan inflasi yang tinggi cenderung mempertimbangkan 
perkembangan nilai tukar dalam melakukan kebijakan moneternya.Oleh karena itu, peneliti mengajukan hipotesis 1 sebagai berikut

Hipotesis 1: Nilai Tukar berpengaruh positif terhadap Inflasi

\section{Pengaruh Jumlah Uang Beredar terhadap Inflasi}

Berry et al., (2007) meneliti tentang pengaruh peningkatan kredit dan permintaan uang terhadap inflasi riil di Inggris. Penelitian tersebut menunjukkan bahwa kontraksi peningkatan uang dalam peredaran akan memicu inflasi, dimana peningkatan jumlah uang beredar dan peningkatan kredit menandai peningkatan permintaan atas harga barang dan jasa dan akhirnya memicu inflasi. Oleh karena itu, peneliti mengajukan hipotesis 2 sebagai berikut:

Hipotesis 2: Jumlah Uang Beredar berpengaruh positif terhadap Inflasi

\section{Pengaruh Inflasi Periode Sebelumnya terhadap Inflasi}

Penelitian oleh Monfared dan Akın (2017) menganalisis hubungan antara ekspektasi inflasi dan inflasi riil di Iran periode 1976 sampai dengan 2012 dengan menggunakan VAR. Hasil penelitian menunjukkan bahwa inflasi dipengaruhi oleh inflasi sebelumnya sampai tiga periode sebelumnya. Selain itu, nilai tukar sampai enam periode sebelumnya berpengaruh positif pada inflasi. Hal tersebut menunjukkan bahwa ekspektasi inflasi memiliki peranan penting pada pembentukan inflasi periode setelahnya. Oleh karena itu, peneliti mengajukan hipotesis 3 sebagai berikut:

Hipotesis 3: Inflasi Periode Sebelumnya berpengaruh positif terhadap Inflasi

\section{Pengaruh Inflation Targeting Framework (ITF) terhadap Inflasi}

Penelitian tentang efektivitas rezim ITF dilakukan oleh Rachman (2015). Hasil penelitiannya menyatakan bahwa rezim ITF mampu mempengaruhi tingkat inflasi dimana ia menyatakan bahwa instrumen moneter dalam pasar uang tidak mampu mempengaruhi tingkat harga, karena hanya berfokus pada demand-pull inflation, tidak pada cosh-push inflation. Selain itu, hasil penelitian jua menyebutkan, base money targeting sudah tidak mampu lagi mempengaruhi tingkat inflasi di Hungaria, Iceland, Meksiko, Norwegia, dan Korea Selatan. Oleh karena itu, peneliti mengajukan hipotesis 3 sebagai berikut:

Hipotesis 3: Inflation Targeting Framework berpengaruh terhadap Inflasi

\section{Kerangka Penelitian}

Berdasarkan teori yang diungkapkan di atas, maka peneliti mengembangkan konsep penelitian dalam penelitian ini adalah sebagai berikut:

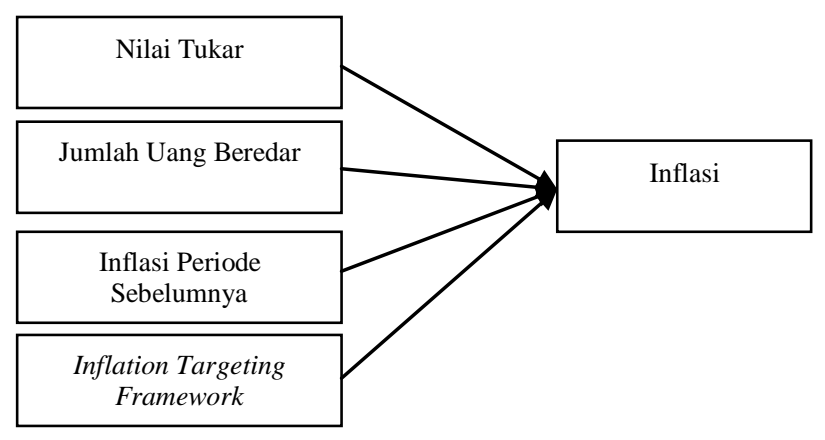

Gambar 2. Kerangka Penelitian 


\section{METODE PENELITIAN}

Penelitian ini berjenis kuantitatif karena menggunakan data-data yang dapat dihitung berkaitan dengan masalah penelitian. Data yang digunakan dalam penelitian ini merupakan data sekunder yang diperoleh dari website data ekonmi Bank Sentral Amerika The Fed (www.fred.stlouisfed.org). Teknik analisis dalam penelitian ini adalah regresi berganda. Penelitian ini menggunakan lima variabel, yaitu Inflasi sebagai variabel dependen dan nilai tukar spot Rupiah/USD, Jumlah Uang Beredar dalam arti sempit (M1), Inflasi Periode Sebelumnya, dan Dummy Inflation Targeting Framework (ITF) sebagai variabel independen.Sampel data yang digunakan dalam penelitian ini adalah data tahunan dari tahun 1992 sampai dengan 2018.

\section{Definisi Operasional Variabel}

Variabel merupakan titik utama dari sebuah penelitian. Berikut ini adalah operasional variabel yang digunakan dalam penelitian ini:

Inflasi sebagai variabel dependen (Y).

Data Inflasi diperoleh dari bentuk transformasi logaritma dari Indeks Harga Konsumen Indonesia (CPI) tahunan periode 1991 sampai dengan 2018. Berikut operasional variabel Inflasi yang digunakan dalam penelitian ini:

\section{LOG_INFLATION = Logaritma Indeks Harga Konsumen}

Nilai Tukar Spot Rupiah/USD sebagai variabel independen (X1). Data nilai tukar ini menggunakan data tahunan periode 1991 sampai dengan tahun 2018. Berikut operasional variabel Nilai Tukar dalam penelitian ini:

\section{LOG_ER = Logaritma Nilai Tukar Spot Rupiah/USD}

Jumlah Uang Beredar dalam arti sempit sebagai variabel independen (X2). Data yang M1 yang digunakan adalah data tahunan periode tahun 1991 sampai dengan tahun 2018. Berikut operasional variabel Jumlah Uang Beredar dalam penelitian ini:

\section{LOG_M1= Logaritma Jumlah Uang Beredar dalam arti sempit}

Inflasi Periode Sebelumnya sebagai variabel independen (X3). Data ini diperoleh dari nilai lag satu periode kebelakang dari nilai logaritma Indeks Harga Konsumen Indonesia (CPI). Oleh karena itu, data yang digunakan adalah dari tahun 1992 sampai dengan tahun 2018. Berikut operasional variabel Inflasi Sebelumnya:

\section{LOG_INFLATION(-1) = Lag Logaritma Indeks Harga Konsumen}

Inflation Targeting Framework sebagai variabel independen dummy (D1). Variabel ini menggunakan nilai dummy yaitu nilai 0 untuk periode sebelum 2005 atau dari 1991 sampai dengan 2004 dan nilai 1 untuk periode 2005 sampai 2018. Berikut operasional variabel Inflation Targeting Framework:

$$
\text { ITF }=\text { Dummy }
$$

\section{Uji Asumsi Klasik}

Suatu persamaan regresi harus memiliki estimasi yang BLUE (Best, Linear, Unbias Estimator) (Algifari, 2015). Oleh karena pengujian asumsi klasik harus dilakukan guna menghasilkan estimasi regresi yang konsisten dan tidak menyesatkan. Pengujian asumsi klasik dalam penelitian ini adalah: Uji Normalitas dengan menggunakan metode Jarque Bera, Uji Multikolinearitas, Uji Autokorelasi dengan menggunakan metode Breusch Godfrey dan Uji Heterokesdasitas dengan menggunakan metode Glejser. 


\section{Uji Parsial}

Uji koefisien regresi atau uji parsial bertujuan untuk menguji hipotesis tentang pengaruh parsial variabel independen terhadap variabel dependen (Algifari, 2015). Tingkat alpha yang digunakan dalam penelitian ini adalah 5\%. Artinya, resiko kesalahan dalam penelitian ini adalah $5 \%$.

Pengambilan keputusan uji parsial dalam penelitian ini adalah sebagai berikut: Apabila nilai signifikansi > alpha 5\%, Ha atau hipotesis yang diajukan, tidak terbukti. Artinya variabel independen tidak berpengaruh secara parsial terhadap variabel independen. Sebaliknya, apabila nilai signifikansi < alpha 5\%, Ha atau hipotesis yang diajukan, terbukti. Artinya variabel independen berpengaruh secara parsial terhadap variabel independen.

\section{HASIL DAN PEMBAHASAN}

\section{Uji Asumsi Klasik}

\section{Uji Normalitas}

Data berdistribusi normal adalah syarat pertama dalam regresi berganda. Pengujian dengan menggunakan metode Jarque Bera digunakan untuk menentukan apakah data dalam penelitian ini berdistribusi normal atau tidak. Berikut hasil dari pengujian normalitas;

Tabel 2. Uji Normalitas

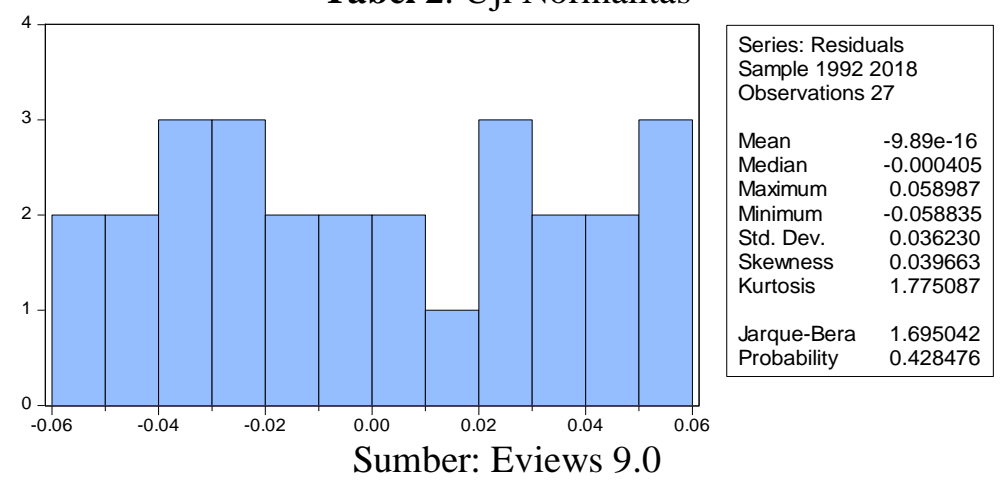

Berdasarkan Tabel 4.1, diketahui bahwa nilai probability dari Jarque-Bera adalah 0,428, dimana nilai ini lebih besar dari alpha 5\%. Artinya, data memiliki distribusi normal dan dapat dilanjutkan ke pengujian selanjutnya.

Uji Multikolinearitas

Pengujian selanjutnya adalah Uji Multikolinearitas guna mengetahui apakah terdapat hubungan linear antar variabel. Nilai rule of thumb dalam penelitian ini adalah 0,80. Artinya, jika antarvariabel memiliki nilai korelasi di atas 0,80 maka terjadi Multikolinearitas. Sebalikya, apabila nilai korelasi antarvariabel di bawah 0,80 maka tidak terjadi Multikolinearitas. Berikut hasil uji Multikolinearitas

Tabel 3. Uji Multikolinearitas

$\begin{array}{cccccc} & \text { LOG_INFLATION } & \text { LOG_ER } & \text { LOG_M1 } & \text { LOG_INFLATION(-1) } & \text { ITF } \\ \text { LOG_INFLATION } & 1.000000 & 0.926358 & 0.986891 & 0.991357 & 0.840366 \\ \text { LOG_ER } & 0.926358 & 1.000000 & 0.869664 & 0.891691 & 0.632072 \\ \text { LOG_M1 } & 0.986891 & 0.869664 & 1.000000 & 0.988426 & 0.858560 \\ \text { LOG_INFLATION(-1) } & 0.991357 & 0.891691 & 0.988426 & 1.000000 & 0.846436 \\ \text { ITF } & 0.840366 & 0.632072 & 0.858560 & 0.846436 & 1.000000\end{array}$

Sumber: Eviews 9.0 
Dari Tabel 4.2 terlihat bahwa terjadi Multikolinearitas karena nilai korelasi di setiap variabel di atas 0,80. Menurut Widarjono (2018), meskipun terjadi Multikolinearitas dalam variabel, estimasi regresi tetap dapat digunakan dan tetap menghasilkan estimasi yang BLUE karena estimasi BLUE tidak mencakup asumsi adanya hubungan antarvariabel independen.

\section{Uji Autokorelasi}

Pengujian Autokorelasi digunakan untuk mengetahui apakah terjadi korelasi yang kuat antarobservasi dalam satu variabel. Pengujian Autokorelasi dalam penelitian ini menggunakan metode Breusch-Godfrey LM. Berikut hasil uji Autokorelasi;

Tabel 4. Uji Autokorelasi

Breusch-Godfrey Serial Correlation LM Test:

\begin{tabular}{llll}
\hline \hline F-statistic & 0.838243 & Prob. F(2,20) & 0.4471 \\
Obs*R-squared & 2.088214 & Prob. Chi-Square(2) & 0.3520 \\
\hline \hline
\end{tabular}

Sumber: Eviews 9.0

Berdasarkan Tabel 4.3, nilai probabiliy Obs*R-squared bernilai 0,352 dimana nilai ini lebih dari alpha 5\%. Artinya, Autokorelasi tidak terjadi dalam regresi yang digunakan.

\section{Uji Heterokesdasitas}

Pengujian Heterokesdasitas digunakan untuk menguji ada tidaknya varians residual antarpengamatan yang berubah. Penelitian ini menggunakan metode Glejser untuk pengujian Heterokesdasitas.

Tabel 5. Uji Heterokesdasitas

Heteroskedasticity Test: Glejser

\begin{tabular}{llll}
\hline \hline F-statistic & 8.148223 & Prob. F(4,22) & 0.0003 \\
Obs*R-squared & 16.11946 & Prob. Chi-Square(4) & 0.0029 \\
Scaled explained SS & 8.960549 & Prob. Chi-Square(4) & 0.0621 \\
\hline \hline
\end{tabular}

Sumber: Eviews 9.0

Berdasarkan Tabel 4.4 di atas, diketauhi nilai probability Obs*R-Squared adalah 0,0029 dimana nilai tersebut lebih kecil dari alpha 5\%. Artinya, terjadi masalah Heterokesdasitas dalam model. Oleh karena itu, untuk menyembuhkan masalah Heterokesdasitas, penelitian ini menggunakan Huber-White Covariance untuk mengkoreksi standard error agar konsisten kemudian dapat dilakukan uji parsial.

\section{Hasil Regresi}

Perbaikan masalah heterokesdasitas dalam penelitian ini menggunakan metode regresi dengan Huber-White. Berikut hasil regresi setelah perbaikan Heterokesdasitas; 
Tabel 6. Hasil Regresi Huber-White

\begin{tabular}{|c|c|c|c|c|}
\hline LOG_ER & 0.327119 & 0.041360 & 7.909064 & 0.0000 \\
\hline LOG_M1 & 0.219022 & 0.049915 & 4.387929 & 0.0002 \\
\hline LOG_INFLĀTION(-1) & 0.287888 & 0.109559 & 2.627689 & 0.0154 \\
\hline ITF & 0.147401 & 0.035060 & 4.204311 & 0.0004 \\
\hline C & -4.475195 & 0.809669 & -5.527192 & 0.0000 \\
\hline
\end{tabular}

Sumber: Eviews 9.0

\section{Pengujian Hipotesis}

Pengujian pengaruh variabel LOG_ER terhadap LOG_INFLATION menunjukkan koefisien positif sebesar 0,327119 dengan nilai signifikansi sebesar 0,000 dimana nilai signifikansi lebih kecil dari alpha 5\%. Artinya, hipotesis 1 yang menyatakan Nilai Tukar berpengaruh positif terhadap Inflasi terbukti.

Pengujian pengaruh variabel LOG_M1 terhadap LOG_INFLATION menunjukkan koefisien positif sebesar 0.219022 dengan nilai signifikansi sebesar 0,0002 dimana nilai signifikansi tersebut lebih kecil daripada alpha 5\%. Artinya, hipotesis 2 yang menyatakan Jumlah Uang Beredar berpengaruh positif terhadap Inflasi terbukti.

Pengujian pengaruh variabel LOG_INFLATION(-1) terhadap LOG_INFLATION menunjukkan koefisien positif sebesar 0.287888 dan nilai signifikansi sebesar 0,0154 dimana nilai signifikansi ini lebih kecil dari alpha 5\%. Artinya, hipotesis 3 yang menyatakan Inflasi Periode Sebelumnya berpengaruh positif terhadap Inflasi terbukti.

Pengujian pengaruh variabel dummy ITF terhadap LOG_INFLATION menunjukkan koefisien positif sebesar 0,147401 dan signifikansi sebesar 0,0004 dimana nilai signifikansi ini lebih kecil daripada alpha 5\%. Artinya, hipotesis 4 yang menyatakan Inflation Targeting Framework berpengaruh terhadap Inflasi terbukti.

\section{PEMBAHASAN}

\section{Pengaruh Nilai Tukar terhadap Inflasi}

Hasil pengujian membuktikan bahwa nilai tukar memiliki pengaruh positif terhadap inflasi. Terdepresiasinya Rupiah atas Dolar akan memicu kenaikaninflasi. Hal tersebut dapat terjadi baik melalui direct-pass through maupun indirect-pass through. Pengaruh direct-pass through dapat terjadi melalui harga domestik yang diimpor dari negara lain. Dimana kenaikan harga barang jadi impor akan memicu tingkat harga domestik. Sementara itu, pengaruh indirectpass through terhadap inflasi domestikterjadi dari kenaikan harga bahan baku impor.

Menurut Liu dan Chen (2017) pengaruh volatilitas nilai tukar terhadap inflasi lebih kuat terjadi pada rezim moneter mengambang terkendali, hal tersebut terjadi karena tingkat intervensi otoritas moneter di sektor pasar uang begitu terbatas. Sehingga ketika permintaan barang impor meningkat, akan memicu kenaikan tingkat harga domestik. Oleh karena itu, Bank Indonesia harus terus menjaga volatilitas nilai nilai rupiah khususnya melalui jalur transmisi 
kebijakan yang bersifat akomodatif guna mendorong peningkatan penawaran domestik. Intervensi baik melalui pasar uang dan kebijakan suku bunga yang efektif dan sangat diperlukan selain untuk menjaga tingkat permintaan domestik juga untuk menjaga arus modal masuk dan keluar dari Indonesia.

\section{Pengaruh Jumlah Uang Beredar terhadap Inflasi}

Hasil pengujian menunjukkan bahwa Jumlah Uang Beredar berpengaruh positif terhadap Inflasi.Peningkatan jumlah uang secara agregat akan meningkatkan tingkat harga. Meskipun Bank Indonesia telah meninggalkan rezim base money targetingsebagai kerangka kebijakan moneternya, namun nampaknya pengendalian permintaan uang masih dapat digunakan sebagai transmisi operasional dari target inflasi.

Kontrol Bank Indonesia atas sirkulasi uang dapat memprediksi tingkat inflasi. Hal ini terjadi karena ketika Bank Indonesia meningkatkan penawaran uang, akan terjadi perubahan perilaku dari sektor riil, dimana peningkatan uang akan cenderung membuat masyarakat meningkatkan konsumsinya. Kemudian di lain sisi, produsen akan melihat peningkatan konsumsi sebagai celah untuk meningkatkan harga.

\section{Pengaruh Inflasi Periode Sebelumnya terhadap Inflasi}

Hasil pengujian menunjukkan bahwa Inflasi Periode Sebelumnya berpengaruh positif terhadap Inflasi. Hal ini terjadi karena perilaku backward looking sektor riil sebagai perkiraan inflasi di masa mendatang, dimana hal tersebut turut serta membentuk ekspektasi tingkat harga yang terjadi pada masa mendatang. Kemudian hasil ini juga membutktikan bahwa kredibilitas Bank Indonesia dalam menetapkan sasaran inflasi masih dipertanyakan, karena menurut hasil pengujian ini tingkat inflasi masa lalu secara signfikan mempengaruhi tingkat inflasi yang akan terjadi di masa depan.

Menurut Dewayany (2012), pengaruh kuat inflasi masa lalu juga disebabkan oleh shocks ekonomi seperti kenaikan harga BBM khususnya premium bersubsidi, tarif dasar listrik dan gangguan distribusi sehingga shocks tersebut membentuk perilaku pelaku ekonomi yang bersifat backward looking.

\section{Pengaruh Dummy Inflation Targeting Framework terhadap Inflasi}

Hasil pengujian menunjukkan bahwa Dummy ITF berpengaruh terhadap inflasi. Hal ini dapat menjadi refleksi bagi Bank Indonesia bahwa implementasi kerangka kebijakan moneter ITF sudah cukup baik dilaksanakan. Meskipun pada faktanya, baru sejak 2015, target inflasi efektif dicapai secara beruntun.

Kebijakan ITF sangat memerlukan kredibilitas bank sentral, dimana bank sentral mengumumkan target inflasi dan berusaha mencapai inflasi aktual di dalam jangkauan target inflasi. Kebijakan ini dilakukan dengan forward looking, yaitu dengan mengevaluasi apakah realisasi inflasi sudah sesuai dengan target yang telah ditetapkan sebelumnya atau tidak. Berdasarkan hasil penelitian ini, nampaknya realisasi inflasi pada masa depan akan terus stabil di dalam target yang ditetapkan dengan syarat tidak ada guncangan yang signifikan mempengaruhi tingkat harga konsumen di Indonesia. 


\section{PENUTUP}

\section{Simpulan}

Berdasarkan hasil pengujian dan pembahasan yang dilakukan, kesimpulan yang dapat dirangkum adalah sebagai berikut; Pertama, Nilai Tukar berpengaruh positif dan signifikan terhadap Inflasi dimana hasil ini mendukung hipotesis pertama yang diajukan. Kedua, Jumlah Uang Beredar berpengaruh positif dan signifikan terhadap Inflasi, hasil ini mendukung hipotesis kedua yang diajukan. Ketiga, Inflasi Periode Sebelumnya berpengaruh positif dan signifikan terhadap inflasi di Indonesia dimana hasil ini mendukung hipotesis ketiga yang diajukan. Terakhir, Dummy ITF berpengaruh terhadap inflasi dimana hasil ini mendukung hipotesis keempat yang diajukan.

\section{Saran}

Berkenaan dengan penelitian selanjutnya, saran yang dapat diberikan khususnya mengenai inflasi di Indonesi adalah: Pertama, pada penelitian ini ditemukan bahwa inflasi periode sebelumnya adalah salah satu pembentuk tingkat inflasi. Oleh karena itu peneliti selanjutnya diharapkan menambahkan faktor-faktor pembentuk inflasi selain inflasi periode sebelumnya, misalnya harga impor, imported inflation dan sebagainya. Kedua, penelitian ini menggunakan data tahuan, dimana data tahunan kurang mampu untuk menggambarkan guncangan yang terjadi. Oleh karena itu, peneliti selanjutnya diharapkan menambah jumlah data menjadi data bulanan atau data kuartalan.

\section{REFERENSI}

Agung, J., Astiyah, S., Sukowati, E., Prastowo, N. J., Muttaqin, M. F., \& Ismal, R. (2001). Identifikasi Variabel Informasi Dalam Framework Inflation Targeting. (2000), 59-77.

Algifari. (2015). Analisis Regresi Untuk Bisnis dan Ekonomi (Third). Yogyakarta: BPFE.

Aprileven, H. P. (2013). Pengaruh Faktor Ekonomi Terhadap Inflasi Yang Dimediasi Oleh Jumlah Uang Beredar. EDAJ: Economics Development Analysis Journal, 2(4), 446-455.

Bernanke, B. S., \& Mishkin, F. S. (1997). Inflation Targeting: A New Framework for Monetary Policy? In Journal of Economic Perspectives (Vol. 11). https://doi.org/10.1257/jep.11.2.97

Berry, S., Harrison, R., Thomas, R., \& De Weymarn, I. (2007). Interpreting Movements in Broad Money.Bank of England Quarterly Bulletin, Q3, 376-388. Retrieved from http://papers.ssrn.com/abstract=1017232

Carare, A., \& Stone, M. . (2003). Inflation Targeting Regimes (No. WP/03/9).

Debelle, G., \& Fischer, S. (1995). How Independent Should A Central Bank Be? In J. Fuhrer (Ed.),Goals, Guidelines and Constraints Facing Monetary Policymakers (pp. 195-221). Boston.

Dewayany, H. P. (2012). ANALISIS PENGARUH FLUKTUASI NILAI TUKAR RUPIAH PASACA PENERAPAN "NILAI TUKAR MENGAMBANG TERKENDALI" DAN IMPLIKASI PENERAPAN INFLATION TARGETING FRAMEWORK (ITF) TERHADAP INFLASI DI INDONESIA. Universitas Indonesia, Jakarta.

Edwards, S. (2006). The Relationship Between Exchange Rates And Inflation Targeting Revisited. In Working Paper 12163 (No. 12163). https://doi.org/10.1016/00221996(78)90025-9 
Erceg, C. J., \& Levin, A. T. (2003). Imperfect credibility and inflation persistence.Journal of Monetary Economics, 50(4), 915-944. https://doi.org/10.1016/S0304-3932(03)00036-9

Hakim, R., Ismail, M., \& Hoetoro, A. (2017). Kredibilitas Bank Sentral Dan Persistensi Inflasi Di Indonesia.EKUITAS (Jurnal Ekonomi Dan Keuangan), 17(2), 155. https://doi.org/10.24034/j25485024.y2013.v17.i2.2237

Ismail, M. (2006). Inflation Targeting Dan Tantangan. Jurnal Ekonomi Dan Bisnis Indonesia, $21(2), 105-121$.

Koku, P. S., Caushi, A., Fetai, A., \& Fetai, B. (2016). The relationship between exchange rate and inflation: the case of Western Balkans Countries. Pressacademia, 5(4), 360-364. https://doi.org/10.17261/pressacademia.2017.358

Latumaerissa, J. R. (2011). Bank dan Lembaga Keuangan Lain. Jakarta: Salemba Empat.

Liu, H. Y., \& Chen, X. L. (2017). The imported price, inflation and exchange rate pass-through in China. Cogent Economics and Finance, 5(1). https://doi.org/10.1080/23322039.2017.1279814

Monfared, S. S., \& Akın, F. (2017). the Relationship Between Exchage Rates and Inflation: the Case of Iran.European Journal of Sustainable Development, 6(4), 329-340. https://doi.org/10.14207/ejsd.2017.v6n4p329

Musa, S. (2008). Membedah Krisis Perbankan. Jakarta: SAD Satria Bhakti.

Ningsih, S., \& Kristiyanti, L. (2018). Analisis pengaruh jumlah uang beredar, suku bunga, dan nilai tukar terhadap inflasi di indonesia periode 2014-2016.Jurnal Ekonomi Manajemen Sumber Daya, 20(2), 96-103.

Rachman, F. (2015). "Does Inflation Targeting Framework Make a Significant Difference in Lowering Price Level?" What is Its Implication to Indonesia's Inflation Rate?Economics and Finance in Indonesia, 61(2), 131. https://doi.org/10.7454/efi.v61i2.508

Salvatore, D. (1997). Ekonomi Internasional. Jakarta: Erlangga.

Setiawan, A. (2011). INFLATION TARGETING FRAMEWORK DAN PERUBAHAN RESPON KEBIJAKAN MONETER. Universitas Indonesia, Jakarta.

Sukirno, S. (2004). Pengantar Teori Makroekonomi. Jakarta: PT Raja Grafindo Persada.

Vega, M., \& Winkelried, D. (2005). "Inflation Targeting and Inflation Behavior : A Successful Story ?"International Journal of Central Banking, 1(3), 153-175.

Widarjono, A. (2018). Ekonometrika Pengantar dan Aplikasinya Disertai Panduan Eviews. Yogyakarta: UPP STIM YKPN. 